\title{
TURYSTYCZNE APLIKACJE MOBILNE - OCENA FUNKCJONALNOŚCI OPROGRAMOWANIA VISITMALOPOLSKA
}

\author{
Iryna Manczak ${ }^{\mathrm{a}}$ (D), Maria Bajak ${ }^{\mathrm{b}}$ \\ ${ }^{a}$ Uniwersytet Ekonomiczny w Krakowie, Kolegium Nauk o Zarządzaniu i Jakości, Instytut Zarządzania, \\ Katedra Handlu i Instytucji Rynkowych; https://orcid.org/0000-0002-9661-9945; e-mail: manczaki@uek.krakow.pl \\ ${ }^{\mathrm{b}}$ Uniwersytet Ekonomiczny w Krakowie, Kolegium Nauk o Zarządzaniu i Jakości, Instytut Zarządzania, Katedra Marketingu; \\ https://orcid.org/0000-0003-4769-7696; e-mail: bajakm@uek.krakow.pl
}

\begin{abstract}
ABSTRAKT
Celem artykułu jest ocena funkcjonalności aplikacji mobilnej VisitMalopolska. Autorki podjęły próbę zaprezentowania rozwiązań umożliwiających samodzielne zwiedzanie Małopolski, jak również ułatwiających dostęp do informacji turystycznych na temat regionu. W opracowaniu zwrócono uwagę na różnorodne wykorzystanie aplikacji mobilnych w turystyce. W dalszej części rozważań omówiono cele i zastosowaną metodę badawczą. Główna część artykułu dotyczy charakterystyki i oceny najważniejszych funkcjonalności nowej aplikacji turystycznej VisitMalopolska. W tym celu posłużono się metodą punktową.
\end{abstract}

\section{SŁOWA KLUCZOWE}

technologie mobilne, aplikacje mobilne w turystyce, Małopolska, VisitMalopolska

\section{INFORMACJE O ARTYKULE}

Przyjęto:

20 października $2020 \mathrm{r}$.

Zaakceptowano:

13 kwietnia $2021 \mathrm{r}$.

Opublikowano:

11 czerwca $2021 \mathrm{r}$.

\section{WSTĘP}

Współczesne technologie mobilne umożliwiają znajdowanie użytecznych rozwiązań w wielu obszarach gospodarki. Dowodem na to są produkty opracowane w wyniku zastosowania wspomnianych technologii. Warto zwrócić uwagę na fakt, że w ostatnim czasie odnotowano znaczny wzrost krajowej liczby użytkowników urządzeń mobilnych. Pod koniec 2018 r. stwierdzono, że po raz pierwszy liczba polskich internautów korzystających ze smartfonów lub tabletów była większa niż osób korzystających z komputerów stacjonarnych (Dąbrowski, 2019). Przywołane dane mogą stać się inspiracją dla podmiotów zainteresowanych wdrażaniem projektów, które zakładają udostępnianie rozwiązań mobilnych. Rozwiązania te umożliwiają realizację zasadniczych zadań z obszaru komunikacji rynkowej (Sznajder, 2014). Należy dodać, że technologie mobilne miały wpływ na powstanie platform komunikacyjnych, pozwalających na dostarczanie usług za pośrednictwem wielokanałowych mediów bez utraty integralności i jakości ich treści (Kachniewska, 2019).

Technologie mobilne stanowią nieodłączny element codziennego życia zarówno z perspektywy użytkowników indywidualnych, jak i różnorakich podmiotów (Martin, Ertzberger, 2013; Parys, 2016). Przykładem takich technologii są aplikacje mobilne, które należy uznać za pokłosie implementacji technik informacyjnych i komunikacyjnych w praktyce gospodarczej (Czajkowski, Nowakowski, 2015) oraz jedno z podstawowych narzędzi marketingu mobilnego (Zawadzki, 2018). Aplikacje te pełnią przede wszystkim funkcję społecznościowa, rozrywkowa, edukacyjną i informacyjną (Kubiak, 2015). Od dłuższego czasu znajdują one także zastosowanie w turystyce (Liang, Schuckert, Law, Masiero, 2017; Pawłowska-Legwand, 2019; da Silva, da Rocha, 2012). Można zauważyć, że ze względu na oferowany turystom bogaty zbiór udogodnień, w tym 
aplikacje mobilne, podróżowanie $\mathrm{w}$ dobie technologii informacyjno-komunikacyjnych zmieniło swój dotychczasowy charakter (Dorcic, Komsic, Markovic, 2019; Gadziński, 2018; Niemczyk, 2017; Tan, Lee, Lin, Ooi, 2017). Uczestnicy ruchu turystycznego mają większe możliwości w zakresie organizacji podróży turystycznych bez pomocy biur podróży (Papińska-Kasperek, 2013). W tym celu korzystają m.in. z aplikacji mobilnych.

Aplikacje mobilne stosowane są w obsłudze ruchu turystycznego na poziomie krajowym, jak również międzynarodowym (Lee, Choi, 2016). Najczęściej stanowią istotny element systemu informacji turystycznej (Zawadzki, 2018) oraz są przydatnym rozwiązaniem podczas uprawiania turystyki miejskiej (Papińska-Kacperek, 2016). Tego typu oprogramowania umożliwiają turystom samodzielne opracowywanie tras zwiedzania, $w$ tym szybkie znalezienie poszukiwanych punktów w bliskim sąsiedztwie (Piechota, 2014). Popularnym rozwiązaniem są także aplikacje mobilne z funkcją tłumaczenia zwrotów na różne języki, dzięki czemu możliwe jest załatwienie wszystkich formalności podczas wyjazdu (Rasińska, Siwiński, 2015). Turyści mają też do dyspozycji np. udostępniane przez muzea aplikacje, które ułatwiają użytkownikom zapoznawanie się z zasobami tych instytucji oraz prowadzoną przez nie działalnością (Gmiterek, 2017; de Rosset, Zielonka, 2016).

W artykule podjęto próbę dokonania oceny najważniejszych funkcjonalności oferowanych $w$ ramach aplikacji mobilnej VisitMalopolska. Analizowana aplikacja stanowi element projektu „m_MSIT - mobilny Małopolski System Informacji Turystycznej". Projekt ten został zainicjowany przez samorząd województwa małopolskiego w latach 2014-2020. Ocenę funkcjonalności analizowanej aplikacji przeprowadzono, wykorzystując metodę punktową. W opracowaniu zwrócono także uwage na wybrane zagadnienia dotyczące zastosowania aplikacji mobilnych w turystyce.

\section{APLIKACJE MOBILNE W TURYSTYCE}

Aplikacje mobilne z powodzeniem wykorzystywane są w turystyce. Branża ta ma także znaczący wpływ na rozwój tych technologii (Kim, Kim, 2017). Zastosowanie aplikacji mobilnych $\mathrm{w}$ turystyce nie jest nowym zjawiskiem (Brown, Chalmers, 2003; Buhalis, Law, 2008). Wręcz przeciwnie - można wskazać liczne przykłady ich wdrażania w działalności turystycznej (Law, Cheng Chu Chan, Wang, 2018; Nunes, Mayer, 2014). Jednak nadal uzasadnione jest inicjowanie przedsięwzięć, które zakładają szerokie zastosowanie aplikacji mobilnych w praktyce gospodarczej. Działania te należałoby potraktować jako inicjatywy o charakterze perspektywicznym, w tym użyteczne w odniesieniu do oczekiwań różnych grup interesariuszy (m.in. turystów, podmiotów branży turystycznej, samorządu gospodarczego, samorządu terytorialnego). Warto dodać, że aplikacje mobilne stanowią przykład narzędzi, nad którymi można mieć kontrolę. Co istotne, po wdrożeniu aplikacje przeważnie nie wymagają nakładów finansowych, poza ponoszeniem kosztów utrzymania, czy też wynikających z rozwijania danego oprogramowania (Zawadzki, 2018). Pogląd ten może mieć szczególne znaczenie oraz implikować liczne korzyści z punktu widzenia podmiotów realizujących projekty oparte na omawianych aplikacjach.

Aplikacje mobilne stanowią rodzaj oprogramowania, które zasadniczo zostało zaprojektowane na telefony komórkowe. Sa to rozwiązania płatne lub darmowe, w zdecydowanej większości dostępne w sklepach internetowych Google Play i Apple Store (Zawadzki, 2018). Aplikacje mobilne można podzielić na (Hamza, Hammad, 2020; Sharma, Kumar, 2020):

- aplikacje natywne (native apps) - są przygotowane na konkretne urządzenia mobilne i system wgrany na tych urządzeniach. Opracowywane są w określonym języku programowania i powiązane ze specyficzną platformą mobilną (np. Android, iOS);

- aplikacje responsywne (responsive web apps) - specjalna wersja strony internetowej, która jest dodatkowo przystosowana do obsługi przez urządzenia mobilne; aplikacje hybrydowe (hybrid apps) - oprogramowania kompatybilne z różnymi systemami, które mogą wykorzystywać funkcjonalności telefonu (np. aparat, GPS, kalendarz itd.). Łączą zalety aplikacji natywnych i webowych, obecnie jest to najpopularniejszy rodzaj programów.

Przyjmując za kryterium przeznaczenie aplikacji mobilnych, można wyróżnić np.: aplikacje informacyjne, oprogramowania edukacyjne, programy społecznościowe, aplikacje biznesowe i oprogramowania biurowe, programy finansowe i bankowe, aplikacje zakupowe, programy nawigacyjne i lokalizacyjne, aplikacje turystyczne, programy zdrowotne i sportowe, gry i oprogramowania rozrywkowe, programy muzyczne i filmowe. Opierając się na zaproponowanej klasyfikacji, należy uznać, że aplikacje mobilne mogą mieć różne funkcje i zastosowanie. W praktyce większość dostępnych aplikacji łączy funkcjonalności z wymienionych obszarów.

Wdrożenie koncepcji innowacyjnych na obszarach turystycznych może przyczynić się - dzięki aktywnej polityce turystycznej danego regionu - do znacznego podniesienia poziomu jego atrakcyjności turystycznej, a także wpływać na konkurencyjność obszarów i oddziaływać na wielkość ruchu turystycznego (Panasiuk, 2015). Ze względu na różnorodność regionalnej oferty turystycznej konieczna jest współpraca pomiędzy przedstawicielami konkurencyjnych obszarów recepcji turystycznej polegająca na tworzeniu spójnej oferty, 
ale wyróżniającej dany region na tle innych (Manczak, 2014). Cel ten może być osiągnięty w ramach projektów realizowanych w celu opracowania i udostępnienia aplikacji mobilnych. Należy dodać, że turystyczne produkty mobilne tworzone są często na zlecenie podmiotów publicznych, które dostrzegają potrzebę przygotowania witryn internetowych oraz programów na urządzenia mobilne, jak również udostępnienia na nich darmowych materiałów multimedialnych (Papińska-Kacperek, 2016).

Z badań przeprowadzonych przez Pawłowską-Legwand (2019) wynika, że turyści chętnie korzystają $\mathrm{z}$ technologii informacyjno-komunikacyjnych przed wyjazdem. Największe zainteresowanie wykazują oni narzędziami cyfrowymi, które umożliwiają dostęp do różnych informacji ułatwiających organizację wycieczki. Przede wszystkim dotyczą one planowania, przemieszczania się oraz korzystania z wybranych atrakcji turystycznych. Grupę najbardziej popularnych aplikacji mobilnych tworzą także mobilne przewodniki oraz programy komunikacyjne, dzięki którym da się wyszukać miejsca parkingowe lub połączenia transportu miejskiego oraz zamówić taksówki (Papińska-Kacperek, 2016).

Wdrożenie aplikacji mobilnych umożliwia dużą interakcję z uczestnikami ruchu turystycznego, a tym samym pomaga $\mathrm{w}$ dostosowaniu produktu do ich oczekiwań (Piechota, 2014). Warto podkreślić, że w zachowaniu konsumentów korzystających z tego typu rozwiązań widać pewien dysonans. $Z$ jednej strony korzystają oni ze znanych już wcześniej narzędzi na podstawie swoich dotychczasowych nawyków. Z drugiej strony wciąż poszukują nowych, bardziej zaawansowanych technologicznie możliwości w celu optymalizacji procesu planowania doświadczenia turystycznego (Xiang, Magnini, Fesenmaier, 2015). Im odbiorca lepiej poznaje daną technologię, tym intensywniej odczuwa doświadczenia z nią związane. Neuhofer, Buhalis i Ladkin (2014) wyróżnili kilka poziomów odczuwania wsparcia technologicznego przez turystę:

- doświadczenie konwencjonalne,

- doświadczenie wspomagane przez technologię,

- doświadczenie wzbogacane przez technologię,

- doświadczenie stymulowane technologią.

Z tym poglądem łączy się pojęcie „inteligentnego" turysty (smart tourist), który przed wyjazdem oraz podczas niego korzysta z różnorodnych dostępnych narzędzi cyfrowych, obejmujących m.in. aplikacje, różnorodne czujniki, Wi-Fi, big data i in. (Gretzel, Sigala, Xiang, Koo, 2015). Proces łączenia doświadczeń konwencjonalnych i technologicznych jest czynnikiem wzmagającym turystyczną atrakcyjność miejsc docelowych, w szczególności dla tego typu turystów (Brennan, 2020; Buonincontri, Micera, 2016). Warto nadmienić, że według danych przedstawionych w raporcie Turyści 2019 niemal połowa użytkowników smartfonów z systemem Android korzysta z turystycznych aplikacji mobilnych.
Co więcej, na podstawie pomiarów z poprzednich lat zauważalna jest tendencja wzrostowa (Spicy Mobile, 2019). W świetle zgłoszonych uwag można przyjąć, że oprogramowania te stanowią jeden $\mathrm{z}$ fundamentalnych elementów smart tourism.

Uwzględniając możliwości aplikacji mobilnych, a także preferencje ich użytkowników, należy stwierdzić, że takie rozwiązania zyskują swoich zwolenników wśród uczestników ruchu turystycznego. Warto zwrócić uwagę na fakt, że tego typu oprogramowania mają różną formę. Na polskim rynku dostępnych jest wiele rozwiązań kierowanych do różnych grup odbiorców. Są to:

- mapy i systemy nawigacyjne (np. Traseo. Szlaki, trasy, mapy);

- aplikacje do planowania transportu w czasie podróży (np. Koleo, e-podróżnik.pl, BlaBlaCar);

- oprogramowania do rezerwacji noclegów (np. Meteor24, Niedrogie hotele, Booking.com, Airbnb);

- przewodniki turystyczne po instytucjach kultury (np. Wilanów Guide, Muzeum Książąt Czartoryskich, Muzeum Śląskie);

- programy wspierające turystykę kwalifikowaną (np. Kajaktour, Szlaki Tatry, Green Velo);

- aplikacje przeznaczone dla uczestników wydarzeń kulturalnych (np. Pol'And'Rock, Jewish Culture Festival, Rzeszowski Festiwal Jazzowy);

- miejskie aplikacje turystyczne (np. Bydgoszcz - Mobilny Przewodnik; Gdańsk, Gdynia, Sopot, Hel. Przewodnik po Trójmieście; Mobilny Przemyśl; Częstochowa - przewodnik);

- regionalne aplikacje turystyczne (VisitMalopolska, Konstelacje dobrych miejsc - Paszport Turystyczny, Karkonosze, Bieszczady \& Górny San).

Na upowszechnienie się aplikacji mobilnych i różnorodność pozycji dostępnych w Polsce, w tym nieustanne pojawianie się nowych propozycji, mogą mieć wpływ zjawiska zachodzące na współczesnym rynku turystycznym. Należy zauważyć, że coraz częściej turyści poszukują ofert spersonalizowanych, m.in. uwzględniających ich indywidualne oczekiwania i preferencje (Manchak, Sanak-Kosmowska, 2018). Należy również podkreślić, że konieczne jest tworzenie coraz bardziej dynamicznych, elastycznych $\mathrm{i}$ inteligentnych rozwiązań o charakterze otwartym, dzięki którym możliwe będzie zaspokajanie potrzeb odbiorców w czasie rzeczywistym (Perez Pulido, 2016). W spełnianiu tych oczekiwań mogą być przydatne również turystyczne aplikacje mobilne.

\section{Cel badań I zastosowana MEtoda badawCZa}

Głównym celem artykułu jest ocena funkcjonalności dostępnych w aplikacji turystycznej VisitMalopolska. Uwzględniając przyjęty cel badawczy, postanowiono 
rozpoznać rozwiązania umożliwiające samodzielne zwiedzanie Małopolski oraz ułatwiające dostęp do informacji turystycznych na temat tego regionu.

Na potrzeby prowadzonych rozważań opracowano następujące pytania szczegółowe:

- Jakie są najważniejsze zadania analizowanej aplikacji?

- Kim są odbiorcy docelowi aplikacji?

- Jakie nowe technologie wykorzystuje aplikacja?

- Jak aplikacja przyczynia się do promowania Małopolski?

- W jak sposób aplikacja wpływa na rozwój turystyki $\mathrm{w}$ regionie?

W artykule podjęto próbę zidentyfikowania możliwości stwarzanych przez wybraną aplikację mobilną. W osiągnięciu tak postawionego celu niezwykle istotna była analiza literatury przedmiotu oraz materiałów na temat omawianego projektu. Zdecydowano się dokonać oceny punktowej funkcjonalności dostępnych w aplikacji z perspektywy różnych grup docelowych. W literaturze przedmiotu zakłada się, że metoda punktowa pozwala ocenić dowolny obiekt według zbioru przyjętych kryteriów (Gierszewska, Romanowska, 2017; Szyran-Resiak, 2016). Istotą tej metody jest stworzenie listy kryteriów (czynników), dzięki którym będzie można opisać i wyróżnić analizowany obiekt (Thompson, Strickland, 1997). Przyjętym kryteriom przypisywane są odpowiednie wagi (nie każde $\mathrm{z}$ nich ma to samo znaczenie) oraz liczby punktów (ocen) z wybranego przedziału liczbowego (Szyran-Resiak, 2016). Jedną z zasad ustalania wagi przyjętych kryteriów oceny jest ich kwalifikowanie za pomocą metody opinii ekspertów (Ziernicka-Wojtaszek, Zawora, 2011). Indywidualne opinie ekspertów dotyczą również określania prawdopodobieństwa subiektywnego, w tym formułowania ocen sprawdzających. Zdaniem Stabryły (2013) te osądy stanowią wypadkową własnych opinii odcinkowych, wydanych na podstawie określonych przesłanek preferencyjnych. Autorki zdecydowały się zastosować niniejsze podejście oraz podjąć próbę oceny głównych funkcjonalności omawianej aplikacji mobilnej. Postanowiły także wykorzystać własne doświadczenia zdobyte podczas korzystania z wybranych programów mobilnych.
W przypadku prowadzonych badań postanowiono dokonać niewielkiej modyfikacji wskazanej metody punktowej. Poszczególne funkcjonalności zostały bowiem ocenione pod kątem użyteczności dla różnych grup docelowych turystów. Przede wszystkim uznano, że potrzeby każdego z użytkowników są w równym stopniu ważne, dlatego zrezygnowano z przyznawania im odmiennych wag. Przyjęto skalę od 1 do 5 punktów, zakładając, że:

- 5 punktów oznacza funkcjonalność bardzo użyteczna;

- 4 punkty oznaczają funkcjonalność przydatną;

- 3 punkty oznaczają funkcjonalność, która może okazać się użyteczna;

- 2 punkty oznaczają funkcjonalność, która jest raczej nieprzydatna;

- 1 punkt oznacza funkcjonalność nieużyteczną.

Punkty otrzymane przez każdą funkcjonalność zostały następnie zsumowane. Funkcjonalności aplikacji VisitMalopolska zostały podzielone według ich przeznaczenia na kilka kategorii oraz poddane ocenie. Dla każdej kategorii została obliczona średnia liczba punktów. Podjęto także próbę wyodrębnienia najważniejszych zadań realizowanych za pomocą aplikacji VisitMalopolska.

\section{APLIKACJA VisitMALOPOLSKA - ZAŁOŻENIA PROJEKTU}

Aplikacja VisitMalopolska stanowi element projektu „m_MSIT - mobilny Małopolski System Informacji Turystycznej", realizowanego w latach 2014-2020 przez samorząd województwa małopolskiego ${ }^{1}$. Podstawowym celem programu jest stworzenie i udostępnienie turystom oraz mieszkańcom regionu platformy cyfrowej, która umożliwi prezentację regionalnej oferty turystycznej z wykorzystaniem nowoczesnych technologii i narzędzi multimedialnych. Projekt „m_MSIT” przewiduje ułatwienie dostępu do informacji z dziedziny turystyki, jak również wspiera samodzielne zwiedzanie Małopolski (VisitMalopolska, 2020a). Realizacja tego celu została podzielona na kilka etapów (tab. 1).

Tabela 1. Etapy realizacji projektu „m_MSIT”

\begin{tabular}{|c|c|}
\hline Etap & \multicolumn{1}{|c|}{ Główne zadania } \\
\hline I & $\begin{array}{l}\text { - rozbudowa systemu udostępniania i prezentacji materiałów związanych z turystyką oraz dziedzictwem } \\
\text { regionalnym poprzez stworzenie portalu internetowego oraz aplikacji mobilnej z planerem podróży } \\
\text { - zakup i zaprogramowanie beaconów łączących się z oprogramowaniem }\end{array}$ \\
\hline II & $\begin{array}{l}\text { - gromadzenie i udostępnianie treści turystycznych (w szczególności związanych z turystyką rowerową) za } \\
\text { pośrednictwem systemu cyfrowego m_MSIT }\end{array}$ \\
\hline III & $\begin{array}{l}\text { - rozbudowa programu poprzez wykorzystanie filmów 360 (w technologii 2D oraz 3D), nagranych w miejscach, } \\
\text { w których znajdują się wybrane atrakcje turystyczne z terenu Małopolski }\end{array}$ \\
\hline
\end{tabular}

Źródło: VisitMalopolska (2020a). 
Aplikacja VisitMalopolska korzysta z funkcjonalności urządzenia, na którym została zainstalowana. Ze względu na przeznaczenie omawiane rozwiązanie może być traktowane jako źródło informacji turystycznych i kulturalnych o regionie oraz danych o charakterze nawigacyjnym i lokalizacyjnym. Aplikacja ta powstała z myślą zarówno o mieszkańcach Małopolski, jak również o turystach krajowych i zagranicznych. $\mathrm{Z}$ tego powodu dostępna jest w ośmiu wersjach językowych (polskiej, angielskiej, niemieckiej, hiszpańskiej, francuskiej, włoskiej, słowackiej i rosyjskiej). Ponadto integrację turystów i mieszkańców regionu wspiera funkcjonalność umożliwiająca tłumaczenie podstawowych zwrotów pomiędzy wymienionymi językami.

Dzięki omawianej aplikacji możliwe jest kierowanie treści do osób poruszających się pieszo, na rowerze oraz w sposób zmotoryzowany. Turysta może wybrać interesujący go rodzaj planowanej wycieczki spośród następujących tematów: „Góry", „Dla dzieci”, ,,Szlak pierwszej wojny", ,"Aktywnie latem / Aktywnie zimą" (w zależności od pory roku), „Sacrum”, czy też „,Turystyka rowerowa". Po wybraniu tematyki treści dostępne w aplikacji są filtrowane według wskazanych preferencji oraz dzielone na następujące kategorie: aktualności, miejsca, wydarzenie oraz trasy turystyczne. Użytkownik może przeglądać te treści wyświetlane $\mathrm{w}$ formie listy, posortowane chronologicznie (aktualności i wydarzenia) lub alfabetycznie (miejsca i trasy turystyczne), jak również jako punkty na mapie (rys. 1).

Zgodnie z założeniami omawianego projektu, w przypadku aplikacji istotne znaczenie ma współpraca $\mathrm{z}$ narzędziami multimedialnymi $\mathrm{w}$ celu prezentacji oferty turystycznej regionu (VisitMalopolska, 2020a).

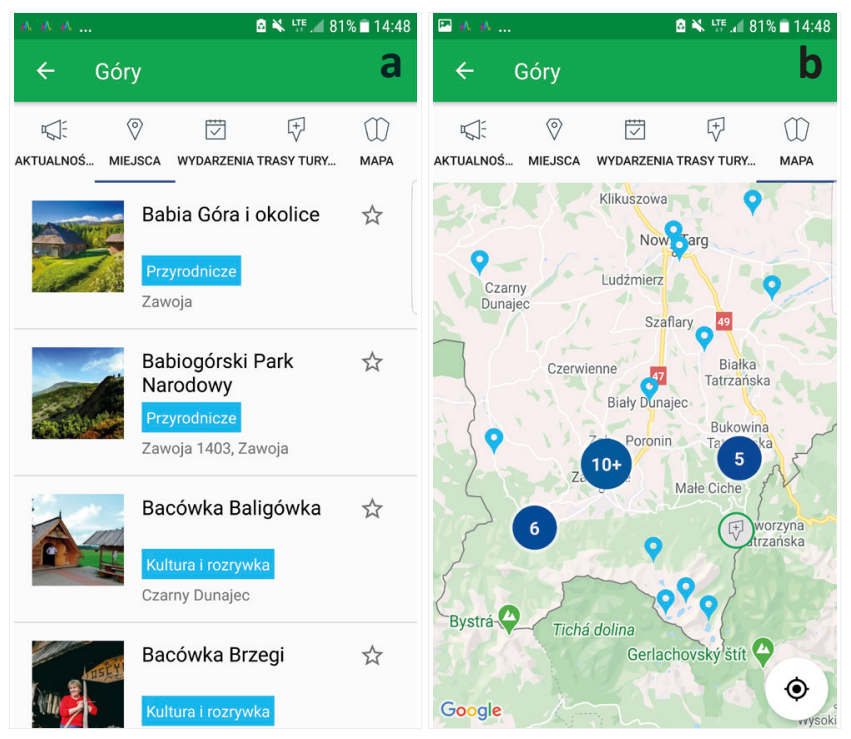

Rysunek 1. Widok ekranu aplikacji VisitMalopolska prezentujący listę atrakcji w województwie małopolskim związanych z tematem "Góry",

zaprezentowanych $w$ formie listy (a) i na mapie (b) Źródło: opracowanie własne
Podstawowe rozwiązania z obszaru nowych technologii zastosowane w ramach programu VisitMalopolska to:

- beacony - sensory wykorzystujące technologię bluetooth do komunikacji z urządzeniem wyposażonym w kompatybilne oprogramowanie (Manczak, Sanak-Kosmowska, Bajak, 2019);

rozszerzona rzeczywistość - system wizualny, nanoszący na otoczenie informacje i obrazki za pośrednictwem środowiska komputerowego (Peddie, 2017);

- sztuczna inteligencja - zbiór różnych technologii, które pozyskuja przetwarzaja, łączą i interpretują dane, moc obliczeniową oraz algorytmy, aby zrealizować założony cel.

Beacony umożliwiają transmisję informacji, mikrolokalizację osób i przedmiotów oraz zbieranie danych na temat ich użytkowników (Manczak, Sanak-Kosmowska, Bajak, 2019). Warto dodać, żew latach 2016-2019 w ramach realizacji projektu „m_MSIT” zainstalowano 1000 beaconów w 183 obiektach w regionie Małopolski. Po znalezieniu się w ich zasięgu użytkownik otrzymuje odpowiednie treści powiązane $\mathrm{z}$ odwiedzanym miejscem (VisitMalopolska, 2020b). Aplikacja VisitMalopolska wykorzystuje również rozszerzoną rzeczywistość. Technologia ta pozwala łączyć rzeczywistość ze światem wirtualnym poprzez symulacje, projekty, ilustracje oraz treści (Peddie, 2017). Dzięki temu możliwe jest uzyskanie automatycznego dostępu do treści związanych z wybraną atrakcją turystyczną po uchwyceniu jej kamerą urządzenia mobilnego (rys. 2a).

Systemy sztucznej inteligencji mogą dostosowywać swoje zachowanie poprzez analizę wcześniejszych rozwiązań oraz uczyć się, wykorzystując model

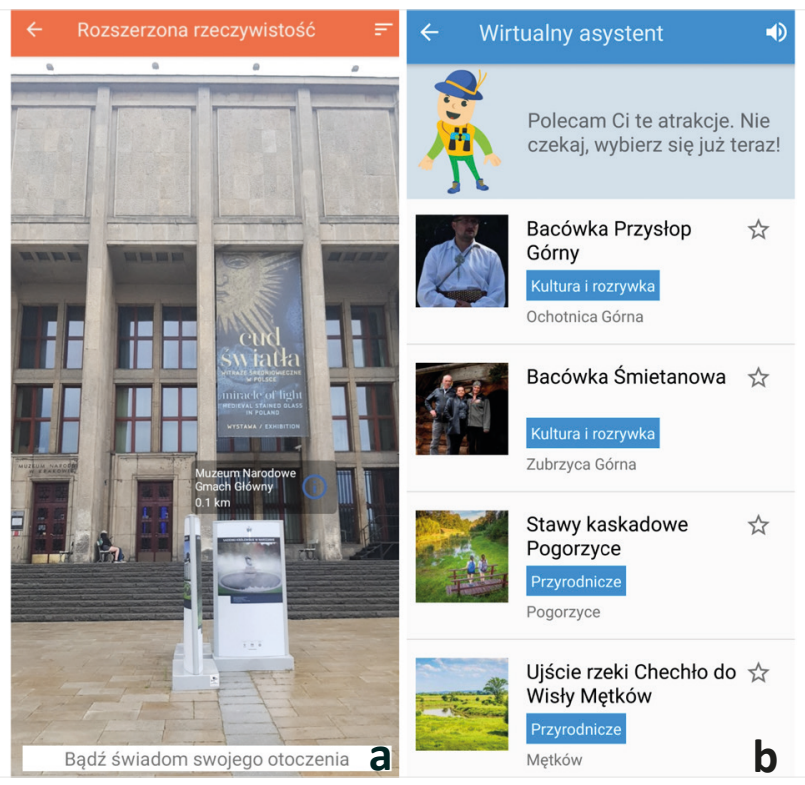

Rysunek 2. Widok ekranu aplikacji VisitMalopolska prezentujący funkcje

związane z rozszerzoną rzeczywistością (a)

i sztuczną inteligencją (b)

Źródło: opracowanie własne 
numeryczny (Komisja Europejska, 2020). Aplikacja VisitMalopolska umożliwia obserwowanie i analizowanie zachowania użytkownika (np. przeglądane miejsca, wydarzenia, trasy czy planowane podróże), w celu zaproponowania mu takich atrakcji turystycznych, które mogą go naprawdę zainteresować (rys. 2b).

\section{OCENA FUNKCJONALNOŚCI APLIKACJI MOBILNEJ VISITMALOPOLSKA}

W badaniach jakości aplikacji mobilnych przyjmuje się różne kryteria. Jednym z nich może być funkcjonalność, definiowana jako dostępność określonych funkcji wybranej aplikacji mobilnej. Do pomiaru funkcjonalności można wykorzystać cechy z obszaru wymagań funkcjonalnych, które zostały wyszczególnione na potrzeby podjętych badań (Zborowski, Łuczak, 2016).

Głównym celem stworzenia aplikacji mobilnej VisitMalopolska było umożliwienie samodzielnego zwiedzania, jak również ułatwienie dostępu do informacji turystycznych na temat regionu (VisitMalopolska, 2020b). Realizację tego zamierzenia umożliwiają funkcjonalności aplikacji oraz starannie dobrane treści podzielone tematycznie (rys. 3). Aplikacja do prawidłowego działania wymaga uruchomienia modułu bluetooth w telefonie oraz włączenia lokalizacji GPS. Ponadto funkcja rozszerzonej rzeczywistości wymaga dostępu do kamery urządzenia. Dopiero wtedy użytkownik może w pełni korzystać ze wszystkich funkcjonalności w ramach aplikacji (tab. 2).
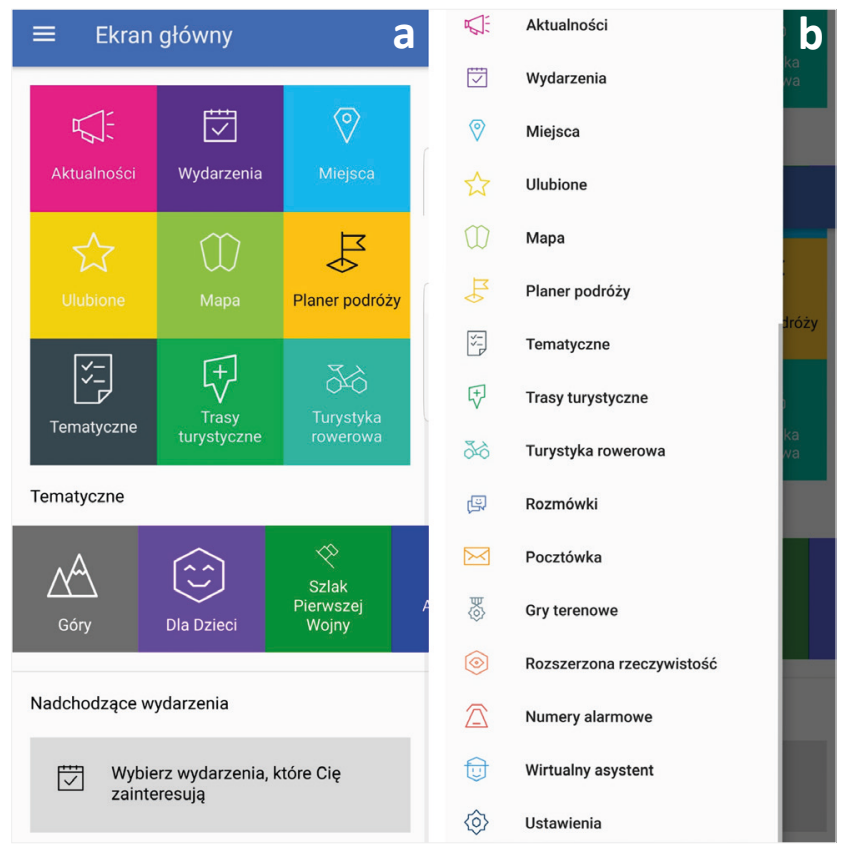

Rysunek 3. Widok ekranu głównego (a) oraz menu bocznego (b) aplikacji VisitMalopolska Źródło: opracowanie własne

Funkcjonalności aplikacji VisitMalopolska można podzielić na cztery kategorie, według ich przeznaczenia:

- kategoria I (atrakcje turystyczne) - „Aktualności”, „Wydarzenia”, „Miejsca” „Tematyczny podział treści", ,"Turystyka rowerowa";

- kategoria II (rozwiązania pomocne przy planowaniu wyjazdu) - ,"Mapa”, ,"Planer podróży", ,"Trasy turystyczne", „Ulubione";

Tabela 2. Przegląd funkcjonalności aplikacji VisitMalopolska

\begin{tabular}{|l|l|}
\hline \multicolumn{1}{|c|}{ Funkcjonalność } & \multicolumn{1}{c|}{ Opis } \\
\hline Aktualności & komunikaty o wydarzeniach, programach oraz inicjatywach realizowanych w regionie Małopolski \\
\hline Wydarzenia & informacje dotyczące regionalnych wydarzeń o charakterze kulturalnym, naukowym i sportowym \\
\hline Miejsca & wyszczególnienie i opisy regionalnych atrakcji turystycznych \\
\hline Ulubione & wykaz treści szczególnie interesujących dla użytkownika \\
\hline Mapa & mapa regionu z zaznaczonymi atrakcjami turystycznymi \\
\hline Planer podróży & narzędzie ułatwiające ułożenie własnego planu wycieczki \\
\hline Tematyczny podział treści & treści dostępne w aplikacji pogrupowane według wybranych tematów \\
\hline Trasy turystyczne & propozycje tras wycieczek po regionie \\
\hline Turystyka rowerowa & treści dotyczące turystyki rowerowej \\
\hline Rozmówki & słownik zwrotów przydatnych w podróży, dostępny w ośmiu językach \\
\hline Pocztówka & kreator wirtualnych kartek pocztowych \\
\hline Gry terenowe & trasy, w ramach których przyznawane są punkty i nagrody \\
\hline Rozszerzona rzeczywistość & nakładka z informacjami o atrakcjach turystycznych widocznych w kamerze telefonu użytkownika \\
\hline Numery alarmowe & wykaz numerów alarmowych \\
\hline Wirtualny asystent & $\begin{array}{l}\text { propozycje atrakcji turystycznych opracowane na podstawie zachowania użytkownika } \\
\text { w obrębie aplikacji }\end{array}$ \\
\hline Ustawienia & narzędzie ręcznego dostosowywania aplikacji do indywidualnych potrzeb \\
\hline
\end{tabular}

Źródło: opracowanie własne. 
- kategoria III (rozwiązania wykorzystywane w trakcie podróży turystycznej) -,,Rozmówki”, ,„Pocztówka", ,"Gry terenowe", ,,Rozszerzona rzeczywistość", "Wirtualny asystent";

- kategoria IV (rozwiązania dotyczące obsługi aplikacji i bezpieczeństwa użytkownika) - „Numery alarmowe", ,Ustawienia".

Wszystkie funkcjonalności aplikacji są ukierunkowane na wsparcie informacyjne osób odbywających podróże turystyczne w regionie Małopolski. Szeroka gama tych funkcjonalności sprawia, że aplikacja może być użyteczna dla różnych typów odbiorców - zarówno dla osób preferujących turystykę pasywną jak i dla tych, które wolą turystykę aktywną.

Wśród wskazanych segmentów odbiorców analizowanej aplikacji można wyróżnić charakterystyczne grupy docelowe, które wyodrębniono na podstawie typologii turystów, zaproponowanej przez Przecławskiego (1979):

- turysta poznawczy - ukierunkowany na zapoznanie się z kultura, naturą i/lub ludźmi;
- turysta integratywny - nastawiony na doświadczenia przeżywane $\mathrm{w}$ grupie;

- turysta zadaniowy - chętny do realizacji skonkretyzowanych działań;

- turysta wyczynowy - zorientowany na aktywność fizyczną i turystykę kwalifikowaną;

- turysta rozrywkowy - poszukujący rozrywki i pasywnego wypoczynku;

- turysta kontemplacyjny - skupiony na sacrum, pielgrzym;

- turysta zdrowotny - zainteresowany ochroną swojego zdrowia.

W celu dokonania oceny użyteczności poszczególnych funkcjonalności analizowanej aplikacji dla różnych grup odbiorców docelowych posłużono się metodą punktową (tab. 3). Zadecydowano o pominięciu w badaniu funkcjonalności z kategorii rozwiązań dotyczących obsługi aplikacji i bezpieczeństwa użytkownika. Na podstawie przeprowadzonej oceny przyjęto, że dla użytkowników aplikacji największe znaczenie mogą mieć funkcje z kategorii rozwiązań wspierających

Tabela 3. Odbiorcy docelowi aplikacji VisitMalopolska

\begin{tabular}{|c|c|c|c|c|c|c|c|c|}
\hline \multirow[b]{2}{*}{ Funkcjonalność } & \multicolumn{7}{|c|}{ Turysta } & \multirow[b]{2}{*}{ Suma } \\
\hline & 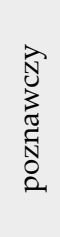 & 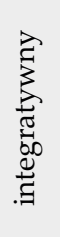 & 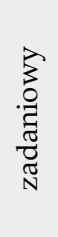 & 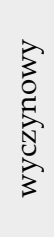 & 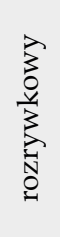 & 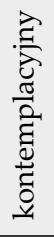 & 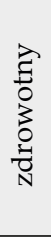 & \\
\hline \multicolumn{9}{|c|}{ Kategoria I - atrakcje turystyczne } \\
\hline Aktualności & 4 & 4 & 3 & 2 & 5 & 3 & 3 & 24 \\
\hline Wydarzenia & 5 & 5 & 3 & 2 & 5 & 4 & 3 & 27 \\
\hline Miejsca & 5 & 2 & 3 & 5 & 4 & 5 & 5 & 29 \\
\hline Tematyczny podział treści & 5 & 5 & 5 & 5 & 5 & 5 & 5 & 35 \\
\hline Turystyka rowerowa & 5 & 3 & 5 & 5 & 2 & 1 & 1 & 22 \\
\hline \multicolumn{8}{|l|}{ Średnia liczba punktów w kategorii I } & 27,4 \\
\hline \multicolumn{9}{|c|}{ Kategoria II - rozwiązania pomocne przy planowaniu wyjazdu } \\
\hline Mapa & 5 & 2 & 5 & 5 & 2 & 5 & 5 & 29 \\
\hline Planer podróży & 5 & 3 & 5 & 5 & 4 & 3 & 3 & 28 \\
\hline Trasy turystyczne & 5 & 2 & 5 & 5 & 4 & 5 & 5 & 31 \\
\hline Ulubione & 5 & 4 & 5 & 5 & 5 & 5 & 5 & 34 \\
\hline \multicolumn{8}{|l|}{ Średnia liczba punktów w kategorii II } & 30,5 \\
\hline \multicolumn{9}{|c|}{ Kategoria III - rozwiązania wykorzystywane w trakcie podróży turystycznej } \\
\hline Rozmówki & 5 & 5 & 3 & 1 & 5 & 1 & 1 & 21 \\
\hline Pocztówka & 2 & 5 & 1 & 1 & 5 & 1 & 1 & 16 \\
\hline Gry terenowe & 5 & 5 & 5 & 3 & 5 & 1 & 1 & 25 \\
\hline Rozszerzona rzeczywistość & 5 & 1 & 3 & 2 & 5 & 1 & 1 & 18 \\
\hline Wirtualny asystent & 5 & 3 & 5 & 4 & 5 & 2 & 2 & 26 \\
\hline \multicolumn{8}{|l|}{ Średnia liczba punktów w kategorii III } & 21,2 \\
\hline SUMA & 66 & 49 & 56 & 50 & 61 & 42 & 41 & 365 \\
\hline
\end{tabular}

Źródło: opracowanie własne. 
planowanie wyjazdu (30,5 pkt). Jako najważniejsze funkcjonalności należy wskazać „Tematyczny podział treści” (35 punktów), „Ulubione” (34 pkt), „Trasy turystyczne" (31 pkt), „Mapa” (29 pkt) oraz "Miejsca” (29 pkt). Ponadto dla przedstawicieli większości grup docelowych użyteczne mogą okazać się takie funkcje, jak: „Planer podróży” (28 pkt), „Wydarzenia” (27 pkt), ,Wirtualny asystent" (26 pkt) i „Gry terenowe” (25 pkt). Można również zauważyć, że turysta poznawczy powinien być traktowany jako główny odbiorca docelowy aplikacji (66 pkt), a za szczególnie ważne typy użytkowników należy uznać także turystę rozrywkowego (61 pkt) oraz zadaniowego (56 pkt).

Punktowe oceny postanowiono zestawić z opiniami użytkowników na temat aplikacji, dostępnymi w sklepie Google Play oraz App Store. Według danych z pierwszego ze sklepów aplikacja została pobrana ponad 5000 razy $^{2}$ od momentu premiery, mającej miejsce w czerwcu 2019 r. Ocenę zdecydowało się przyznać 26 użytkowników i kształtuje się ona na poziomie $3,7 / 5,0$. W sklepie AppStore nie podano informacji o tym, ile osób pobrało aplikację, jednak biorąc pod uwagę liczbę recenzji (4), prawdopodobnie zdecydowanie mniej niż w przypadku Google Play. Właściciele urządzeń z systemem iOS wystawili aplikacji ocenę $3,8 / 5,0$. Aplikację oceniono łącznie 30 razy ze średnią ocen na poziomie 3,71. Najczęściej wymieniane zalety oprogramowania dotyczą:

- interesujących informacji, które są w nim dostępne;

- częstych aktualizacji treści;

- przejrzystości funkcjonalności;

- propozycji przydatnych podczas wycieczek.

Z kolei do najczęściej wymienianych wad aplikacji można zaliczyć:

- brak informacji na temat wybranych atrakcji turystycznych zlokalizowanych w Małopolsce;

- problemy techniczne związane $\mathrm{z}$ wyświetlaniem pewnych treści, np. map, pojawiające się w przypadku niektórych urządzeń;

- nieustanne działanie aplikacji w tle, brak możliwości jej wyłączenia.

Co ważne, negatywne opinie na temat informacji dostępnych w aplikacji pojawiają się rzadko w stosunku do słów pochwały. Warto zauważyć, że w ciągu 1,5 roku od momentu ukazania się oprogramowania VisitMalopolska treści dostępne w aplikacji były systematycznie rozwijane. Obserwacje poczynione pomiędzy wrześniem a grudniem 2020 r. wskazują na to, że baza atrakcji turystycznych jest poszerzana $\mathrm{w}$ dynamicznym tempie, często zgodnie ze wskazanymi w komentarzach oczekiwaniami użytkowników. Za największą wadę aplikacji można uznać pewne trudności techniczne występujące w trakcie jej użytkowania. Niewątpliwie tego rodzaju usterki powinny być na bieżąco niwelowane przez podmiot odpowiedzialny za aplikację (Urząd Marszałkowski Województwa Małopolskiego).
Opierając się na przedstawionych rozważaniach, uznano, że aplikacja VisitMalopolska wspiera turystę w realizacji jego podróży o różnorodnym charakterze. W aplikacji w atrakcyjnej formie zaprezentowane są sposoby organizacji podroży turystycznych w regionie. Poza tym użytkownicy mają możliwość poznania interesujących miejsc oraz łączenia ich samodzielnie lub zgodnie z sugestiami aplikacji w ramach jednej wycieczki. Użytkownicy mogą zapoznawać się z wydarzeniami kulturalnymi odbywającymi się w regionie. Na podstawie dokonanej analizy zauważono, że ze względu na różnorodność dostępnych zastosowań aplikacja może być rozpatrywana jako:

- przewodnik turystyczny po regionie,

- planer podróży,

- informator na temat wydarzeń odbywających się w Małopolsce,

- platforma do grywalizacji,

- system umożliwiający odbywanie wirtualnych podróży po Małopolsce.

Podsumowując, można uznać, że aplikacja mobilna VisitMalopolska stanowi przykład kompleksowego rozwiązania, dzięki któremu możliwe jest spełnianie potrzeb różnych odbiorców docelowych. Co ważne, na podstawie liczby dostępnych funkcjonalności oraz opisanych miejsc, tras i wydarzeń można przyjąć, że jest to projekt nowatorski $w$ kategorii aplikacji mobilnych wpływających na rozwój turystyki w wybranym regionie $w$ Polsce.

\section{PODSUMOWANIE}

Wzrost liczby użytkowników urządzeń mobilnych sprzyja tworzeniu turystycznych aplikacji mobilnych. Bezprzewodowa komunikacja zapewniana przez smartfony umożliwia pozostawanie $\mathrm{w}$ łączności $\mathrm{w}$ zasadzie wszędzie i o każdej porze. W konsekwencji aplikacja mobilna może stanowić narzędzie nieustannie wspierające turystę podczas podróży. $Z$ tego względu coraz więcej regionów oferuje dedykowane rozwiązania skierowane do różnych segmentów ruchu turystycznego.

Warto podkreślić, że szczególne znaczenie mają rozwiązania kompleksowe, które łączą wiele funkcjonalności i dają dostęp do szerokiej gamy interesujących treści. Użytkownik, aby zdecydować się na wykorzystanie aplikacji mobilnej, musi bowiem dostrzegać realne korzyści płynące $z$ jej użytkowania. Jednocześnie ważne jest, aby była ona intuicyjna i łatwa w obsłudze. Na podstawie opinii użytkowników można uznać, że aplikacja mobilna VisitMalopolska jest zgodna ze wskazanymi założeniami. Natomiast niepokojący może wydawać się fakt, że aplikacja do tej pory została pobrana tylko kilka tysięcy razy (wartość szacowana przez autorki to pomiędzy 6000 a 7000 pobrań). Na tle 
ruchu turystycznego w regionie, wynoszącego w $2019 \mathrm{r}$. 17,86 mln osób (Borkowski i in., 2020), jest to znikoma wartość. Należy jednak zauważyć, że aplikacja jest dostępna dopiero od czerwca 2019 r. oraz że od marca 2020 r. do chwili obecnej obowiązują różne ograniczenia związane z pandemią COVID-19. Być może po zniesieniu obostrzeń nastąpi wzrost zainteresowania oprogramowaniem - powinno być ono zatem rozwijane w celu spełnienia wymagania potencjalnych użytkowników.

Warto podkreślić, że treści dostępne w aplikacji są aktualizowane właściwie codziennie oraz dodatkowo selekcjonowane za pomocą mechanizmów sztucznej inteligencji. W konsekwencji program może być na bieżąco personalizowany. Tego typu rozwiązania niewątpliwie sprzyjają wzrostowi dostrzegania użyteczności analizowanej aplikacji mobilnej, jak również umacnianiu przekonania o atrakcyjności oferty wybranego regionu. W przyszłości może się to przekładać na skuteczność inicjowanych, lub też planowanych przedsięwzięć promocyjnych. Na podstawie przeprowadzonych rozważań stwierdzono, że aplikacja VisitMalopolska wspiera turystę $\mathrm{w}$ realizacji jego podróży o różnorodnym charakterze. Stanowi ona przykład kompleksowego rozwiązania, które umożliwia spełnianie potrzeb różnych segmentów ruchu turystycznego.

Zakres badań zaprezentowanych w artykule był ograniczony. Wiązało się to w głównej mierze z wykorzystaniem metody punktowej, która cechuje się dużą subiektywnością. Zaprezentowane wyniki mająjednak charakter wstępny. Podjęta dyskusja pomoże przeprowadzić szerszą analizę aplikacji mobilnej z wykorzystaniem metod ilościowych i jakościowych. Wyniki tych badań zostaną zestawione z obserwacjami poczynionymi przez autorki artykułu. Zaproponowane działania pozwolą przeprowadzić kompleksową analizę i sformułować konstruktywne konkluzje badawcze. Planowane jest również dokonanie porównania aplikacji VisitMalopolska z innymi rozwiązaniami tego typu dostępnymi na polskim rynku.

\section{PRZYPISY}

${ }^{1}$ Projekt został zrealizowany ze środków finansowych Regionalnego Programu Operacyjnego Województwa Małopolskiego na lata 2014-2020, współfinansowanego przez Unię Europejską.

${ }^{2}$ Stan na 7 grudnia $2020 \mathrm{r}$.

\section{BIBLIOGRAFIA}

Borkowski, K., Grabiński T., Seweryn, R., Rotter, L., Mazanek, L., Grabińska, E. (2020). Ruch turystyczny w Małopolsce w 2019 roku. Kraków: Małopolska Organizacja Turystyczna.

Brennan, B. (2020). A convergence of mobile device application use and smart tourism: A comparison of Korean and Non-Korean smart tourists. The Journal of Internet Electronic
Commerce Research, 20 (4), 145-160. https://doi.org/10.37272/ JIECR.2020.08.20.4.145

Brown, B., Chalmers, M. (2003). Tourism and mobile technology. Proceedings of the European Conference of Computer Supported Cooperative Work (ECSCW) (s. 335-354). Cham: Springer. https://doi.org/10.1007/978-94-010-0068-0_18

Buhalis, D., Law, R. (2008). Progress in information technology and tourism management: 20 years on and 10 years after the Internet - the state of eTourism research. Tourism Management, 29 (4), 609-623. https://doi.org/10.1016/j.tourman.2008.01.005 Buonincontri, P., Micera, R. (2016). The experience co-creation in smart tourism destinations: A multiplecase analysis of European destinations. Information Technology and Tourism, 16 (3), 285-315. https://doi.org/10.1007/s40558-016-0060-5

Czajkowski, R., Nowakowski, W. (2015). iBeacons - mobilne usługi lokalizacyjne. Elektronika: Konstrukcje, Technologie, Zastosowania, 4, 47-50. http://dx.doi.org/10.15199/13.2015.4.9

Dąbrowski, G. (2019). Dostęp do Internetu w Polsce. W: Internet 2018/2019 (s. 8-9). Pobrane z: https://www.iab.org.pl/wp-content/uploads/2019/06/HBRP-raport-IAB-05-191-1.pdf (20.10.2020).

Dorcic, J., Komsic, J., Markovic, S. (2019). Mobile technologies and applications towards smart tourism - state of the art. Tourism Review, 74 (1), 82-103. https://doi.org/10.1108/TR-07-2017-0121

Gadziński, J. (2018). Perspectives of the use of smartphones in travel behaviour studies: Findings from a literature review and a pilot study. Transportation Research. Part C: Emerging Technologies, 88, 74-86. https://doi.org/10.1016/j.trc.2018.01.011

Gierszewska, G., Romanowska, M. (2017). Analiza strategiczna przedsiębiorstwa. Warszawa: PWE.

Gmiterek, G. (2017). Wykorzystanie aplikacji mobilnych w muzeach - przegląd i analiza polskich projektów. E-mentor, 2 (69), 25-39. http://dx.doi.org/10.15219/em69.1296

Gretzel, U., Sigala, M., Xiang, Z., Koo, C. (2015). Smart tourism: Foundations and developments. Electronic Markets, 25 (3), 179-188. https://doi.org/10.1007/s12525-015-0196-8

Hamza, Z.A., Hammad, M. (2020). Testing approaches for web and mobile applications: An overview. International Journal of Computing and Digital Systems, 9 (4), 657-664. https://dx.doi. org/10.12785/ijcds/090413

Kachniewska, M. (2019). Tworzenie wartości dodanej na bazie kontekstowych aplikacji mobilnych (przypadek branży turystycznej). Kwartalnik Nauko Przedsiębiorstwie, 3, 15-24. https:// doi.org/10.5604/01.3001.0013.4780

Kim, D., Kim, S. (2017). The role of mobile technology in tourism: Patents, articles, news, and mobile tour app reviews. Sustainability, 9 (11), 2082. https://doi.org/10.3390/su9112082

Komisja Europejska (2020). Biała ksiega w sprawie sztucznej inteligencji. Pobrane z: https://ec.europa.eu/info/sites/info/files/ commission-white-paper-artificial-intelligence-feb2020_pl.pdf (20.10.2020).

Kubiak, K. (2015). Ocena wybranych aplikacji mobilnych w opinii użytkowników. Zeszyty Naukowe Uniwersytetu Szczecińskiego, 875. Problemy Zarzadzania, Finansów i Marketingu, 41 (2), 83-93. https://doi.org/10.18276/pzfm.2015.41/2-07

Law, R., Cheng Chu Chan, I., Wang, L. (2018). A comprehensive review of mobile technology use inhospitality and tourism. Journal of Hospitality \& Management, 27 (2), 626-648. https:// doi.org/10.1080/19368623.2018.1423251

Lee, H.E., Choi H.S. (2016). Improvements of the Korean tourism application, visit Korea, for foreigners-based on beacon functions. International Journal of Software Engineering and Its Applications, 10 (4), 103-116. https://doi.org/10.14257/IJSEIA.2016.10.4.11

Liang, S., Schuckert, M., Law, R., Masiero, L. (2017). The relevance of mobile tourism and information technology: An analysis of recent trends and future research directions. Journal of Travel 
and Tourism Marketing, 34 (6), 732-748. https://doi.org/10.108 0/10548408.2016.1218403

Manchak, I., Sanak-Kosmowska, K. (2018). Personalizacja usług jako trend rozwojowy na rynku usług turystycznych. Ekonomiczne Problemy Turystyki, 2 (42), 29-35. https://doi. org/10.18276/ept.2018.2.42-03

Manczak, I. (2014). Kształtowanie relacji partnerskich w turystyce. Przeglad Organizacji, 12, 21-26. https://doi.org/10.33141/ po.2014.12.04

Manczak, I., Sanak-Kosmowska, K., Bajak, M. (2019). Zastosowanie beaconów w komunikacji marketingowej muzeów z osobami niepełnosprawnymi. Zarzadzanie w Kulturze, 20 (4), 551-564. http://dx.doi.org/10.4467/20843976ZK.19.033.11712

Martin, F., Ertzberger, J. (2013). Here and now mobile learning: An experimental study on the use of mobile technology. Computers $\mathcal{E}$ Education, 68, 76-85. https://doi.org/10.1016/j. compedu.2013.04.021

Neuhofer, B., Buhalis, D., Ladkin, A. (2014). A typology of technology-enhanced tourism experiences. International Journal of Tourism Research, 16 (4), 340-350. https://doi.org/10.1002/jtr.1958

Niemczyk, A. (2017). Aplikacje mobilne jako determinanta zachowań turystycznych (na przykładzie Krakowa). Prace Naukowe Uniwersytetu Ekonomicznego we Wrocławiu, 473, 370-380. https:// doi.org/10.15611/pn.2017.473.34

Nunes, M., Mayer, V. (2014). Mobile technology, games and nature areas: The tourist perspective. Tourism $\mathcal{E}$ Management Studies, 10 (1), 53-58.

Panasiuk, A. (2015). Nowoczesne technologie informacyjne w kształtowaniu innowacji na rynku turystycznym. Rozprawy Naukowe Akademii Wychowania Fizycznego we Wroctawiu, 49, 99-106.

Papińska-Kacperek, J. (2013). E-tourism services in Polish tourists' opinions. Problems of Management in the $21^{\text {st }}$ Century, (7) 1, 33-38.

Papińska-Kacperek, J. (2016). Miejskie aplikacje mobilne w turystyce kulturowej w Polsce. Turystyka Kulturowa, 2, 67-85. Pobrane z: http://turystykakulturowa.org/ojs/index.php/tk/ article/view/720/646 (20.10.2020).

Parys, T. (2016). Identyfikacja barier zastosowania technologii mobilnych z perspektywy użytkowników indywidualnych, Studia Ekonomiczne. Zeszyty Naukowe Uniwersytetu Ekonomicznego w Katowicach, 281, 142-154.

Pawłowska-Legwand, A. (2019). Wykorzystanie technologii informacyjno-komunikacyjnych w dostępie do informacji i usług turystycznych w świetle wyników badań przeprowadzonych wśród polskich turystów w województwie małopolskim. Turyzm/Tourism, 29 (2), 109-117. https://doi. org/10.18778/0867-5856.29.2.22

Peddie, J. (2017). Augmented reality: Where we will all live. Cham: Springer International Publishing. https://doi. org/10.1007/978-3-319-54502-8

Perez Pulido, A. (2016). Mobile app for tourist services using artificial intelligence methodologies. Conference on artificial intelligence with applications.

Piechota, N. (2014). Lokalizacyjna aplikacja mobilna jako narzędzie badań ruchu turystycznego miasta w długim okresie. Studia Oeconomica Posnaniensia, 2 (1), 121-135.
Przecławski, K. (1979). Socjologiczne problemy turystyki. Warszawa: Instytut Wydawniczy CRZZ.

Rasińska, R., Siwiński, W. (2015). Aplikacje mobilne jako innowacyjne źródła informacji turystycznej dla studentów. Rozprawy Naukowe Akademii Wychowania Fizycznego we Wroctawiu, 50, 74-80.

de Rosset, A., Zielonka, K. (2016). Aplikacje mobilne w muzeach, moda czy potrzeba? Muzealnictwo, 57, 236-244. https://doi. org/10.5604/04641086.1220430

Sharma, S., Kumar, P. (2020). Rest House Hybrid Mobile Application using Ionic Tool. International Research Journal of Engineering and Technology, 7 (4), 45-50.

da Silva, A.C, da Rocha, H.V. (2012). M-traveling: Mobile applications in tourism. International Journal for Infonomics, 5 (3/4), 618-630. https://doi.org/10.20533/iji.1742.4712.2012.0071

Spicy Mobile (2019). Turyści 2019. Pobrane z: https://spicymobile. pl/assets/doc/Turysci_2019.pdf (15.12.2020).

Stabryła, A. (2013). Metodyka osiągnięć przedsiębiorstwa. Zarzadzanie i Finanse, 4 (1), 317-332.

Sznajder, A. (2014). Technologie mobilne w marketingu. Warszawa: Oficyna a Wolters Kluwer business.

Szyran-Resiak, A. (2016). Systematyka metod pokrewnych możliwych do zastosowania w ocenie jakości działalności marketingowej organizacji. Zeszyty Naukowe PWSZ w Płocku. Nauki Ekonomiczne, XXIII, 87-98.

Tan, G.W.-H., Lee, V.H., Lin, B., Ooi, K.-B. (2017). Mobile applications in tourism: The future of the tourism industry? Industrial Management \& Data Systems, 117 (3), 560-581. https://doi. org/10.1108/IMDS-12-2015-0490

Thompson, A., Strickland, A. (1997). Strategic management. concepts and cases. Boston: Irwin Professional Publishing.

VisitMalopolska (2020a). Projekt m_MSIT - mobilny Małopolski System Informacji Turystycznej. Pobrane z: https://visitmalopolska.pl/projekt-m_msit (20.10.2020).

VisitMalopolska (2020b). Zwiedzaj Małopolske z nowoczesnymi technologiami. Pobrane z: https://visitmalopolska.pl/-/ zwiedzaj-malopolske-z-nowoczesnymi-technologiami(20.10.2020).

Xiang, Z., Magnini, V.P., Fesenmaier, D.R. (2015). Information technology and consumer behavior in travel and tourism: Insights from travel planning using the internet. Journal of Retailing and Consumer Services, 22, 244-249. https://doi. org/10.1016/j.jretconser.2014.08.005

Zawadzki, P. (2018). Aplikacje mobilne jako element systemu informacji turystycznej. Zeszyty Naukowe Uniwersytetu Ekonomicznego w Krakowie, 4 (976), 85-101. https://doi. org/10.15678/ZNUEK.2018.0976.0406

Zborowski, M., Łuczak, K. (2016). Propozycja doboru składowych struktury kryteriów oceny jakości aplikacji mobilnych na przykładzie wybranych bankowych aplikacji mobilnych w Polsce. Annales Univesitas Marie Curie-Skłodowska Lublin-Polonia. Sectio H: Oeconomia, 50 (2), 183-202. https:// doi.org/10.17951/h.2016.50.2.183

Ziernicka-Wojtaszek, A., Zawora, T. (2011). Wybrane metody oceny atrakcyjności agroturystycznej obszarów wiejskich. Infrastruktura i Ekologia Terenów Wiejskich, 2, 235-245. 